\title{
Influence of socio-economic and behavioral risk factors on malaria prevalence: A study from Adilabad District of Telangana State.
}

\author{
M. Anjaneyulu', V. Vanitha Das ${ }^{1 *}$ \\ ${ }^{1}$ Dept. of Zoology, Osmania University, Hyderabad, India \\ *Corresponding Author: profvanitadas@gmail.com, Mobile No.9848121961
}

Available online at: www.isroset.org

Received: 17/Apr/2019, Accepted: 25/Apr/ 2019, Online: 30/Apr/2019

\begin{abstract}
The major burden of vector-borne disease in India comes from malaria. The biggest burden of malaria in India is often observed in backward or poor and remote parts of the country which might be due to the limited access to medical treatment or lack of knowledge on mode of malaria transmission and its preventive measures. A better understanding of the socio-economic, behavioral risk factors and knowledge gaps related to malaria infection are essential when developing coherent and effective policies Socio economic information was collected from 4872 participants in three PHCs (Jainoor, Sirpur, Lingapur) irrespective of their age and gender. The occurrence of malaria was significantly higher in individuals those don't have schooling/primary education compared to secondary/higher education level participants. Malaria infection was observed to be elevated in households with farmers head as compared to households with daily labour or employs. The present study demonstrates that those variables related to education and poor health infrastructure are the most important factors in reducing the risk of malaria infection.
\end{abstract}

Keywords - Malaria, Vector borne diseases, Prevalence, Infection, Parasites, Preventive measures

\section{INTRODUCTION}

In India, vector-borne diseases such as malaria, chikungunya, dengue, kala-azar, lymphatic filariasis Japanese and encephalitis (JE) have considerable influence on morbidity and mortality. The epidemiology of the vectorborne diseases may differ considerably, owing to economic, sociocultural, ecology and behavioral factors. Inhabitants of rural, urban slums and tribal areas are often at risk from such vector-borne diseases, which particularly affect the poor and vulnerable population [1], [2]. Vector-borne diseases are account for disability and deaths South Asian countries, especially in poor people as they have limited access to timely and effective treatment.

The major burden of vector-borne disease in India comes from malaria. Malaria is a life threatening disease caused by protozoan parasites such as Plasmodium vivax, Plasmodium falciparum, Plasmodium malariae and Plasmodium ovale that are transmitted through the bite of infected Anopheles mosquitoes. Malaria referred as a disease of antiquity or poverty and is a formidable deterrent to the cultural and socioeconomic development of man in tropical and subtropical areas [3]. Malaria also prevents foreign investments and tourism into new regions which further significantly hampers the economic development of the country [4]. The incidence of malaria infection is more in African and South Asian countries. According to WHO reports (2016), about 91 countries and territories had been infected by malaria and nearly 3.2 billion people, i.e nearly half the world's population were at risk of malaria infection. The year saw an estimated 216 million malaria cases and 445000 deaths due to malaria infection worldwide. Moreover, it was reported that India accounted for $6 \%$ of all malaria cases in the world, $6 \%$ of the deaths, and $51 \%$ of the global $P$. vivax cases.

The biggest burden of malaria in India is often observed in backward or poor and remote parts of the country which might be due to the limited access to medical treatment or lack of knowledge on mode of malaria transmission and its preventive measures. A better understanding of the socioeconomic, behavioral risk factors and knowledge gaps related to malaria infection are essential when developing coherent and effective policies and tools to tackle malaria in endemic areas of the world including India [5], [6]. 
Knowledge on malaria infection and socio-economic status are key factors to acquire the appropriate control strategies. Large number of risk factors influence malaria occurrence including knowledge about malaria transmission and prevention, demography and socio-economic status of the individuals. Since the socio-economic status, behaviors of communities and their adherence to malaria control programs has been used as an indicator to characterize malaria treatment, the present study was conducted to assess the influence of household social economic status, knowledge, attitude and practice on treatment seeking behaviors, distance to health facilities on prevalence of malaria in Adilabad district of Telangana state.

\section{METHODOLOGY}

Socio economic information was collected from 4872 participants in three PHCs (Jainoor, Sirpur, Lingapur) irrespective of their age and gender. Information on the socio-economic factors such as house type, human behavior such as sleeping habits clothing habits, repellants, education, knowledge on malaria disease and treatment, income, breeding site near house, treatment place, nutrition and community etc. was collected using specific proforma. Informed and written consent was taken from all participants under the study. This study was approved by institutional ethical committee, Osmania University. Statistical analysis was carried out by using SPSS software (version 20.0)

\section{RESULTS}

The demographic characteristics of the participants were given in table 1. Out of 4872 participants (1037 households), $49.0 \%$ were males and $51.0 \%$ were females. The mean age of the participants was $37.4 \pm 1.9$ (mean age, SD). The education level of $76.0 \%$ of the participants had no schooling or primary schooling and $24.0 \%$ of participants were had secondary or higher education. Among total households, $65.3 \%$ were had knowledge about free medicine whereas $34.7 \%$ were not aware of the free medicine. Most households $(66.3 \%)$ were lived near to breeding sites and $33.7 \%$ were lived far away from breeding sites. Maximum number of households $(75.2 \%)$ were having live stocks at their living place. Malaria history was also observed in above 10 years age group (71.8\%). The percentage of participants/households with respect to knowledge about free nets, use of bed nets, house type, monthly income, information source and treatment was more or less similar.

The occurrence of malaria was significantly higher in individuals those don't have schooling/primary education compared to secondary/higher education level participants $(\mathrm{p}=0.02)$ (Table 2). More malaria cases were observed in individuals those lived in conventional house types $(\mathrm{p}=0.003)$ compared to individuals lived in improved house type. We did not observe any association between family income of the participants and malaria occurrence. Households with farmers head were significantly infected with malaria $(p=0.01)$ as compared to households with daily labour or employs. Information sources such as news papers, radio and TV were not associated with the occurrence of malaria. Further, significant association was observed between malaria occurrence and individuals sharing the house with live stock $(\mathrm{p}=0.02)$.

The prevalence of malaria was high in households who had poor knowledge about free supply of bed nets (521/1037, $50.2 \%$ ) and observed that the percentage of those individuals was high in Lingapoor PHC (41.1\%) (Table 3). Further, malaria occurrence was significantly higher in households (688/1037) who had lived near to mosquito breeding sites $(\mathrm{p}=0.04)$ as compared to individuals lived far away from the breeding sites (349/10.7). Among, 37.6\% household were belongs to jainoor PHC. Also, the occurrence of malaria was more in households who have poor knowledge about free supply of medicine $(677 / 1037 ; 65.3 \%)$ as compared to households who have knowledge about free medicine. It is observed high incidence of malaria in households who do not use bed nets during their bed time compared households who regularly use bed nets in their houses $(\mathrm{p}=0.01)$. More number of households $(53.2 \%)$ were reported as malaria is not a preventable disease, out of these households, $35.6 \%$ were belong to Jainoor PHC. About $71 \%$ of malaria infected persons were below the age of 14 years among, $40 \%$ of the participants belong to Jainoor PHC.

\section{Discussion}

In our study population, the occurrence of malaria among both sexes was similar which was in accordance with previous studies from different geographical regions [4],[5],[7]. However, few studies have been reported that females were more susceptible to malaria infection as they are engage in household activities which make them to be at a greater risk of acquiring the malaria infection [8]. The level of education of the participants has showed significant influence on the occurrence of malaria. Individuals with illiteracy and primary education level were mostly affected by malaria infection compared to individuals with high schooling and above education levels. This might be due to the individuals ability towards the personal hygiene and sanitary may improve as they are attending to several academic curriculum related to human health compared to illiterate people. It was observed that the malaria occurrence was also high in farmers and individuals who were lived in conventional type of houses (huts) and with livestock forming livelihood. It can be attributed that poorly constructed houses with grass or bamboo sticks might have gaps and holes through which mosquito could easily contact the human hosts. Previous study had been reported that good quality houses could minimize disease transmission by 
reducing the human-mosquito contact [9]. Farmers and individuals who have livestock farming might have received mosquito bite more frequently as the cattle dung, irrigation land with water lodge are habitat for mosquito breeding resulted in increase in vector abundance.

Further, the occurrence of malaria significantly associated with breeding sites and use of bed nets. The households who did not use bed nets frequently were affected by malaria as compared to those who used bed nets every night which suggesting that use of bed nets may reduce the chance of mosquito bite. Also, malaria occurrence was observed to be higher among individuals who were not used bed nets as compared to those used ITNs. Since, individuals with straneous occupation like bus drivers have been infected with malaria [10] educating those groups about usage of bed nets may help to prevent malaria infection. Several studies have reported that ITN coverage was related to malaria control strategies reduced malaria and associated with a malaria risk protective effect [11].

\section{CONCLUSION}

Though malaria occurrence may depend on several variables, the present study demonstrates that those variables related to education and poor health infrastructure are the most important factors in reducing the risk of malaria infection. Our study suggests that proper education and maintenance of hygienic conditions may help in controlling the malaria infection.

Table 1. Demographic characteristics of Malaria infected participants in three PHCs

\begin{tabular}{|l|c|c|}
\hline & \multicolumn{2}{|c|}{$\mathrm{n}$} \\
\hline AGE & & \\
\hline$<12$ & 2,184 & 44.8 \\
\hline $12-50$ & 1,124 & 23.1 \\
\hline$>50$ & 1,568 & 32.1 \\
\hline \multicolumn{1}{|c|}{ SEX } & & \\
\hline Male & 2,390 & 49 \\
\hline Female & 2,482 & 51 \\
\hline EDUCATION & & \\
\hline No schooling/Primary schooling & 3,707 & 76 \\
\hline Secondary/Higher education & 1,169 & 24 \\
\hline $\begin{array}{l}\text { KNOWLEDGE ABOUT FREE } \\
\text { MEDICINE } \\
\text { HOUSE HOLDS) }\end{array}$ & & \\
\hline YES & 677 & 65.3 \\
\hline No & 360 & 34.7 \\
\hline $\begin{array}{l}\text { Knowledge about free nets } \\
\text { (House holds) }\end{array}$ & & \\
\hline YES & 521 & 50.2 \\
\hline No & 516 & 49.8 \\
\hline
\end{tabular}

\begin{tabular}{|l|c|c|}
\hline $\begin{array}{l}\text { Knowledge about breeding sites } \\
\text { (House holds) }\end{array}$ & \\
\hline Running & 402 & 38.8 \\
\hline Stagnant & 635 & 61.2 \\
\hline Near to breeding sites & 688 & 66.3 \\
\hline Yes & 349 & 33.7 \\
\hline No & & \\
\hline Use of bed nets & 365 & 35.2 \\
\hline YES & & \\
\hline LLIN & 321 & 31.0 \\
\hline No & 351 & 33.8 \\
\hline Live stock & & \\
\hline Yes & 778 & 75.02 \\
\hline No & 259 & 24.98 \\
\hline Malaria history & 401 & 71.87 \\
\hline $0-14$ years & 157 & 28.13 \\
\hline$>14$ years & & \\
\hline HousE TYPE & & \\
\hline Conventional & 565 & 59.0 \\
\hline Improved & 392 & 41.0 \\
\hline Monthly Income (Indian Rupees) & & \\
\hline$<5000$ & 404 & 53.5 \\
\hline$>5000$ & 351 & 46.5 \\
\hline Information source & 524 & 50.5 \\
\hline TV/Radio/News Paper & 513 & 49.5 \\
\hline None & & \\
\hline
\end{tabular}

Table 2. Socio-economic characteristics of malaria infected participants in three PHCs

\begin{tabular}{|c|c|c|c|c|c|}
\hline Characteristics & $\begin{array}{l}\mathbf{n}(\% \\
)\end{array}$ & Lingapor & Jainor & Sirpor & -value \\
\hline \multicolumn{6}{|l|}{ Education } \\
\hline $\begin{array}{c}\text { No } \\
\text { schooling/Prima } \\
\text { ry schooling }\end{array}$ & $\begin{array}{c}2672 \\
(54.8 \\
)\end{array}$ & 837 (31.3) & $\begin{array}{c}1076 \\
(40.2)\end{array}$ & $759(28.5)$ & 0.02 \\
\hline $\begin{array}{l}\text { Secondary/ } \\
\text { higher } \\
\text { education }\end{array}$ & $\begin{array}{c}2200 \\
(45.2 \\
) \\
\end{array}$ & $631(28.7)$ & $970(44.1)$ & $599(27.2)$ & \\
\hline \multicolumn{6}{|l|}{ House type } \\
\hline Conventional & $\begin{array}{l}565( \\
59.0)\end{array}$ & $170(30.2)$ & $205(36.2)$ & $190(33.6)$ & $\begin{array}{c}0.00 \\
3\end{array}$ \\
\hline Improved & $\begin{array}{l}396( \\
41.0)\end{array}$ & $159(40.5)$ & $117(29.9)$ & $116(29.6)$ & \\
\hline \multicolumn{6}{|l|}{$\begin{array}{c}\text { Monthly } \\
\text { Income (Indian } \\
\text { Rupees) } \\
\end{array}$} \\
\hline$<5000$ & $\begin{array}{l}404( \\
53.5)\end{array}$ & $170(42.1)$ & $172(42.6)$ & $62(15.3)$ & 0.19 \\
\hline$>5000$ & $\begin{array}{l}351( \\
46.5) \\
\end{array}$ & $162(46.6)$ & $150(42.3)$ & $39(11.1)$ & \\
\hline \multicolumn{6}{|l|}{ Occupation } \\
\hline Daily labour & $\begin{array}{l}266( \\
25.7)\end{array}$ & $101(38.0)$ & $62(23.3)$ & $103(38.7)$ & \\
\hline Former & $\begin{array}{l}652( \\
62.8)\end{array}$ & $194(29.7)$ & $225(34.5)$ & $233(35.8)$ & 0.01 \\
\hline Employe & $\begin{array}{l}119( \\
11.5)\end{array}$ & $34(28.6)$ & $35(29.4)$ & $50(42.0)$ & \\
\hline \multicolumn{6}{|l|}{$\begin{array}{c}\text { Information } \\
\text { source }\end{array}$} \\
\hline $\begin{array}{c}\text { TV/Radio/News } \\
\text { Paper }\end{array}$ & $\begin{array}{l}524( \\
50.5)\end{array}$ & $170(32.5)$ & $172(32.8)$ & $182(34.7)$ & 0.22 \\
\hline
\end{tabular}




\begin{tabular}{|c|c|c|c|c|c|}
\hline None & 513( & $159(31.0)$ & $150(29.2)$ & $204(39.8)$ & \\
& $49.5)$ & & & & \\
\hline Live stock & & & & & \\
\hline Yes & 778( & $251(32.26$ & $224(28.80$ & $303(38.9$ & 0.02 \\
& 75.02 & ) & ) & $4)$ & \\
\hline No & 259( & $78(30.11)$ & $98(37.83)$ & $83(32.06)$ & \\
& 24.98 & & & & \\
\hline & ) & & & & \\
\hline
\end{tabular}

Table 3. Epidemiological characteristics of Malaria infected participants

\begin{tabular}{|c|c|c|c|c|c|}
\hline $\begin{array}{c}\text { Character } \\
\text { istics }\end{array}$ & $\mathbf{n}(\%)$ & Lingapoor & Jainoor & Sirpoor & p-value \\
\hline \multicolumn{6}{|l|}{$\begin{array}{c}\text { Knowled } \\
\text { ge about } \\
\text { free } \\
\text { medicine }\end{array}$} \\
\hline Yes & $360(34.7)$ & $125(34.7)$ & $143(39.7)$ & $92(25.6)$ & 0.30 \\
\hline No & $677(65.3)$ & $207(30.6)$ & $\begin{array}{c}289 \\
(42.7)\end{array}$ & $\begin{array}{c}181(26 . \\
7)\end{array}$ & \\
\hline \multicolumn{6}{|l|}{$\begin{array}{l}\text { Knowled } \\
\text { ge about } \\
\text { free nets }\end{array}$} \\
\hline Yes & $516(49.8)$ & $207(40.1)$ & $158(30.6)$ & $\begin{array}{c}151(29 . \\
3)\end{array}$ & 0.11 \\
\hline No & $521(50.2)$ & $240(41.1)$ & $134(25.7)$ & $\begin{array}{c}147(28 . \\
2)\end{array}$ & \\
\hline \multicolumn{6}{|l|}{$\begin{array}{c}\text { Near to } \\
\text { breeding } \\
\text { site }\end{array}$} \\
\hline Yes & $688(66.3)$ & $258(37.5)$ & $259(37.6)$ & $\begin{array}{c}171(24 . \\
9)\end{array}$ & 0.04 \\
\hline No & $349(33.7)$ & $114(32.7)$ & $123(35.2)$ & $\begin{array}{c}112(32 . \\
1)\end{array}$ & \\
\hline \multicolumn{6}{|l|}{$\begin{array}{c}\text { Breeding } \\
\text { site }\end{array}$} \\
\hline Running & $402(38.8)$ & $158(39.3)$ & $133(33.1)$ & $\begin{array}{c}111(27 . \\
6)\end{array}$ & 0.16 \\
\hline Stagnant & $635(61.2)$ & $215(33.9)$ & $218(34.3)$ & $\begin{array}{c}202(31 . \\
8)\end{array}$ & \\
\hline \multicolumn{6}{|l|}{$\begin{array}{c}\text { Does } \\
\text { Malaria } \\
\text { preventa } \\
\text { ble } \\
\text { disease } \\
\end{array}$} \\
\hline Yes & $485(46.8)$ & $158(32.6)$ & $193(39.8)$ & $\begin{array}{c}134(27 . \\
6)\end{array}$ & 0.42 \\
\hline No & $552(53.2)$ & 192(34.8) & 198(35.9) & $\begin{array}{c}162(29 . \\
3)\end{array}$ & \\
\hline \multicolumn{6}{|l|}{$\begin{array}{c}\text { Use of } \\
\text { bed nets }\end{array}$} \\
\hline Yes & $351(33.8)$ & 111(31.6) & $115(32.8)$ & $\begin{array}{c}125(35 \\
6)\end{array}$ & \\
\hline LLIN & $321(31.0)$ & $140(43.6)$ & $89(27.8)$ & $92(28.6)$ & 0.01 \\
\hline No & $365(35.2)$ & $118(32.3)$ & $123(33.7)$ & $\begin{array}{c}124(34 . \\
0)\end{array}$ & \\
\hline \multicolumn{6}{|l|}{$\begin{array}{c}\text { How does } \\
\text { Malaria } \\
\text { spread }\end{array}$} \\
\hline $\begin{array}{l}\text { Mosquito } \\
\text { bite }\end{array}$ & $365(35.2)$ & $115(31.5)$ & $126(34.5)$ & $\begin{array}{c}124(34 . \\
0)\end{array}$ & 0.22 \\
\hline Water/Air & $321(31.0)$ & $120(37.0)$ & $99(31.0)$ & $\begin{array}{c}102(32 . \\
0)\end{array}$ & \\
\hline $\begin{array}{l}\text { Don't } \\
\text { know }\end{array}$ & $351(33.8)$ & $110(31.0)$ & $112(32.0)$ & $\begin{array}{c}129(37 . \\
0)\end{array}$ & \\
\hline
\end{tabular}

\begin{tabular}{|c|c|c|c|c|c|}
\hline $\begin{array}{c}\text { Malaria } \\
\text { history }\end{array}$ & & & & & \\
\hline $\begin{array}{c}0-14 \\
\text { years }\end{array}$ & $\begin{array}{c}401(71.8 \\
7)\end{array}$ & $100(25.0)$ & $161(40.0)$ & $\begin{array}{c}140(35 . \\
0)\end{array}$ & 0.88 \\
\hline$>15$ years & $\begin{array}{c}157(28.1 \\
3)\end{array}$ & $42(26.75)$ & $60(38.22)$ & $\begin{array}{c}55(35.0 \\
3)\end{array}$ & \\
\hline & & & & & \\
\hline
\end{tabular}

\section{ACKNOWLEDGMENT}

We would like to thank all participants for providing their socio-economic and health information.

\section{REFERENCES}

[1]. Lal Shiv, GPS Dhillon, C.S Agarwal, "Epiderniology and control of malaria", Indian Journal of Pediatrics, Vol. 66, Issue.3, PP. 547-54, 1999.

[2]. CJ. Palmer, "Evaluation of the optimal test for Rapid diagnosis of plasmodium vivax and plasmodium falciparum malaria", Journal of Clinical Microbiology, Vol. 36(1), Issue.8, PP. 203-6, 1998

[3]. D. Gwatkin, M. Guillot, "The burden of disease among the global poor: current situations, future trends, and implications for strategy", American parasitology, Vol. 12, Issue.9, PP. 4-8, 2000.

[4]. JL. Gallup, JD. Sachs, "The economic burden of malaria", American Journal of Tropical Medicine, Vol 64, Issue.6, PP,8596, 2001.

[5]. B. Rabha, D. Goswami, S. Dhiman, NG. Das, PK. Alukdar, MJ. Nath, I. Baruah, RK. Bhola, L. Singh, "A cross sectional investigation of malaria epidemiology among seven tea estates in Assam, India", Journal of Parasitic Disease, Vol, 36, Issue.12, PP, 1-6, 2011.

[6]. K. Yadav, MJ. Nath, PK. Talukdar, PK. Saikia, I. Baruah, L. Singh, "Malaria risk areas of Udalguri district of Assam, India: a GIS-based study", International Journal of Geographical Infermation Science, Vol. 26(1), Issue.5, PP. 123-131, 2012.

[7]. JD. Sachs, "Vector borne disease control strategies", International journal of vector born diseases, Vol. 2, Issue.9, PP. 355-488, 2012.

[8]. DG. Ayele, TT. Ewotir, HG. Mwamb, "Prevalence and risk factors of malaria in Ethiopia", Malaria Journal , Vol. 11, Issue.8, PP. 195-196. 2012.

[9]. A. Hiscox, P. Khammanithong, S. Kaul, P. Sananikhom, R. Luthi, N. Hill, PT. Brey, SW. Lindsay, "Risk factors for mosquito house entry in the Lao PDR", PLoS One, Vol. 8(5), Issue.3, PP. 62769, 2013.

[10]. S. Mukherjee , C. K. Pradhan , I. Chakraborty , A. Saha , S. Thakur, S. Sahu, "General health status and morbidity pattern of bus drivers in West Bengal", International Journal of Scientific Research in Biological Sciences, Vol.5, Issue.4, pp. 29-39, 2018.

[11]. A. Lowassa, HD. Mazigo, AM. Mahande, BJ. Mwangonde, S. Msangi, MJ. Mahande, EE. Kimaro, E. Kweka Elisante, EJ. Kweka, "Social economic factors and malaria transmission in Lower Moshi, Northern Tanzania", Parasitic Vectors, Vol. 5, Issue.2,PP. 129. 2012. 


\section{AUTHORS PROFILE}

Mr. Anjaneyulu completed his MS.c in Zoologyand presently pursuing his Ph.D in Osmania University. His main are of research work focuses on medical entomology.

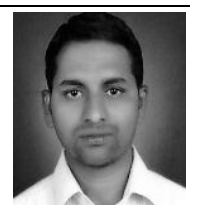

Dr. Vanitha Das working as a Professor in Department of Zoology, Osmania University and heading the Helminthology Lab Dr. V. Vanita Das joined the University in 1989. Her broad area of research is Helminthology and phytonematology with specialization on

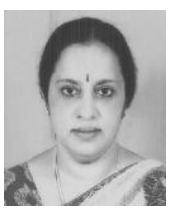
taxonomy, diversity and ecology of helminthes. she has published 12 National and 8 International papers in peer reviewed journals. 